\title{
Calculation of Load Diagrams and Static Characteristics of Multimotor Electric Drive Systems using the Methods of Equivalent Forces and Reduced Moments
}

\author{
Alexander Semenov ${ }^{1 *}$, Ilya Yakushev ${ }^{1}$, Yakov Kharitonov², Vladislav Shevchuk ${ }^{3}$, \\ Elena Gracheva ${ }^{4}$, Svetlana Ilyashenko ${ }^{5}$ \\ ${ }^{1}$ North-Eastern Federal University n.a. M.K. Ammosov, Mirny Polytechnic Institute, 678170, Mirny, Russia \\ ${ }^{2}$ PJSC Alrosa, 678170, Mirny, Russia \\ 3JSC Research and Production Center Polyus, 634050, Tomsk, Russia \\ ${ }^{4}$ Kazan State Power Engineering University, 420066 Kazan, Republic of Tatarstan, Russia \\ 5 Plekhanov Russian University of Economics, Moscow, 117997, Russia
}

\begin{abstract}
This paper presents the calculations and construction of load diagrams and the static characteristics of individual mechanisms of a mining roadheader, which form a multimotor electric drive system, using the methods of equivalent forces and reduced moments. The productivity of the mine and the roadheader are calculated. The operating forces of idle and on-load mechanisms are calculated, and operation time intervals and a complete working cycle are determined. The load diagrams of mechanisms are constructed and their kinematic diagrams are designed. Based on the calculations performed, asynchronous motors with a short-circuit rotor, which have the closest power values and are suitable in terms of voltage and mode of operation, were selected from the catalogue. The gear reduction ratio is calculated, static resistance moments, and operation speeds to the motor shaft are specified. The static characteristics of the most powerful electric motor of a mining roadheader - or cutter - are formulated. The high accuracy of the calculations was confirmed by computer simulation, which showed minimum errors.
\end{abstract}

Keywords: Computer modeling; Electric motor; Equivalent force; Load diagram; Mine; Power calculation; Reduced moment; Roadheader; Static characteristics

\section{Introduction}

Diamond production consists of three main stages: mining, processing and manufacturing of jewelry, and retail. Rough diamond mining is geographically concentrated in South Africa, Russia, Australia, and Canada. Alrosa is developing Russian diamond reserves; it produced 36.7 million carats in 2018. Alrosa's experience in mining rough diamonds may be of interest to other companies (Chanturia et al., 2015). The company's largest deposits are Mir, Yubileinaya, Udachnaya, and Internationalnaya. They are located in Western Yakutia, where the mining of diamond-bearing rocks is now being actively developed (Chaadaev et al., 2015; Sutresman et al., 2017).

A literature review showed that the main direction of current developments in the complex mechanization of tunneling and mining operations in the diamond-mining

*Corresponding author's email: sash-alex@ yandex.ru, Tel.: +79142950425, +74113649002 doi: 10.14716/ijtech.v11i8.4541 
industry is the introduction of combined methods for carrying out work (Sutresman et al., 2017; Hrinov and Khorolskyi, 2018; Cehlar et al., 2019). This determines the relevance and practical significance of the presented research. Its novelty consists in an integrated approach to the application of new methods of calculation and selection of both the mining roadheader itself and its individual mechanisms, since at present, most Alrosa underground mines use the drilling-and-blasting method, which becomes insecure with the deepening of mining operations and the release of gases and oil.

The level of mechanization of tunneling and mining operations in the global diamondmining industry in 2018 reached $80 \%$. In some Canadian mines (for example, Ekati and Diavik), it exceeded $90 \%$. At the same time, in Russia use of the roadheader method does not exceed 50\%. Light and medium roadheaders are mainly used. Heavy mining roadheaders account for only about 20\% (Odnokopylov et al., 2019).

Voest-Alpine Bergtechnik GesmbH (an Austrian manufacturer of mining equipment) produces medium and heavy mining combines of the AM series, which are self-propelled, tracked machines with a boom-type cutter and loading device in the form of paired pallet handles on the inclined rotary table with an independent drive (GES.M.B.H, 2009). The stage of development of pit reserves through an auxiliary ventilation shaft, the size of which does not allow for the transport of the well-proven mining roadheader AM-105 to a working face, started at the Internationalnaya underground mine in Western Yakutia. Prior to this, the AM105 roadheader was used to extract minerals at the 8-11 horizons of the mine and, having worked out 32 thousand $\mathrm{m}^{3} / \mathrm{h}$, depleted its resource. In general, the mining equipment of SANDVIK, which includes Voest-Alpine Bergtechnik GesmbH, has proven itself well not only in the Russian North, but also at the Letlhakane, Jwaneng (Botswana), Venesia (South Africa), and Catoca (Angola) sites in Africa. To continue mining operations, the AM-75 roadheader was delivered to the mine, which has the same modifications but has a lower capacity and dimensions. This roadheader has already been operated in the Far North at the Aikhal and Udachny mines. The authors were interested in the multimotor electric drive system of this complex and its energy performance.

\section{Methods}

This paper presents the calculation of the productivity and selection of a roadheader for a mine, the calculation and construction of load diagrams and static characteristics using the methods of equivalent forces and reduced moments for the roadheader mechanisms and their electric motors, as well as computer modeling of the multimotor electric drive system of the mining roadheader to confirm the accuracy of the calculations.

For the first time, a methodology for calculating and choosing a roadheader in accordance with mining capabilities and economic feasibility of the life of the mine will be used. Also, for the first time, a method for calculating equivalent forces adapted to the mechanisms of the roadheader is used that has proven itself effective for the calculation of the mechanisms of cyclic action (for example, lifting installations at a mine,), as well as the method of the reduced moments, modified taking into account its application at electric motors of technological units of mining enterprises.

Finally, to confirm the accuracy of the calculations, a computer simulation is performed in MatLab (SimPowerSystems library of the Simulink application), widely used for modeling of complex electrical systems with an error not exceeding $10 \%$. 


\section{Results and Discussion}

\subsection{Calculation of Output Capacity and Roadheader Selection}

Previously, the choice of the mining roadheader made by the technicians of the Internationalnaya mine was based only on operational experience at other mines and the overall dimensions necessary for its delivery through the auxiliary ventilation shaft. Therefore, to confirm the validity of choosing the AM-75 mining machine, we performed the necessary calculations.

The output capacity is assessed based on mining capabilities and the economically viable life of the mine, as well as by mining capabilities, taking into account the dip angle of the deposit. With the angle of ore body dip over $30^{\circ}$, the annual output will be determined as follows:

$$
A_{g}=U \cdot K_{1} \cdot K_{2} \cdot K_{3} \cdot K_{4} \cdot m \cdot L_{p r} / \sin \alpha \cdot \rho \cdot(1-W) /(1-D),[t]
$$

where $U$ is the annual decrease of stoping over the entire ore area in metres per year; $K_{1}, K_{2}, K_{3}, K_{4}$ are correction factors, which take into account, respectively, the dip angle, thickness of ore body, mining system, the number of layers in simultaneous mining; $W$ and $D$ are planned values of losses and ore dilution, unit fractions; $\rho$ is the average ore density in tons per cubic metre; $m$ is the width of the ore body in metres; $L_{p r}$ is the undercut length (for weak rocks) in metres; $\alpha$ is the angle of deviation of the ore body from the horizontal axis.

The hourly output capacity of the mine is defined on the basis of the calculated annual output under the condition of deducting planned nonworking days for maintenance and repair of mining equipment (for the Internationalnaya mine in 2019 it was 52 days):

$$
A_{h}=A_{g} /((364-52) \cdot 24),[t / h]
$$

The passport roadheader output capacity is set in $\mathrm{m}^{3} / \mathrm{min}$, obtain the hourly capacity of the roadheader. The hardness of the developed kimberlite rocks varies within $f$ hard $=6 \div 8$, which corresponds to $300 \div 600 \mathrm{~kg} / \mathrm{cm}^{2}$. In this case the rock density will vary within $\rho=$ $2.3 \div 2.6 \mathrm{t} / \mathrm{m}^{3}$, and we get:

$$
Q_{\text {roadh }}=Q_{\text {roadh.m }} \cdot 60 \cdot \rho,[t / h]
$$

Table 1 Main passport characteristics of the AM-75 roadheader

\begin{tabular}{lr}
\hline \multicolumn{1}{c}{ Characteristics } & \multicolumn{1}{c}{ Value } \\
\hline Passport minute productivity $Q_{\text {roadh.m }}$ & $0.5 \mathrm{~m}^{3} / \mathrm{min}$ \\
Total installed electric motor power, $P_{\Sigma}$ & $350 \mathrm{~kW}$ \\
Motor power of the working body $P_{W}$ & $200 \mathrm{~kW}$ \\
Motor power of the loader $P_{L}$ & $2 \times 36 \mathrm{~kW}$ \\
Motor power of the conveyor $P_{C}$ & $70 \mathrm{~kW}$ \\
Diameter of the cutting head of the working body, $D$ & $750 \mathrm{~mm}$ \\
Total weight, $W_{\Sigma}$ & $52 \mathrm{t}$ \\
Mass of the working body, loader and conveyor, $\mathrm{m}_{\mathrm{M}}$ & $8 / 2 \times 1.5 / 5 \mathrm{t}$ \\
Roadheader travel speed (adjustable), $\mathrm{V}_{\mathrm{R}}$ & $(0 \div 18) \mathrm{m} / \mathrm{min}$ \\
Rotation speed of the working body of the roadheader, $V_{W}$ & $1.4 \mathrm{~m} / \mathrm{s}$ \\
\hline
\end{tabular}

In Table 1, we give the main passport data of the roadheader and its mechanisms, which are required for further calculation and construction of the load diagrams and static characteristics. Having calculated the hourly productivity of the roadheader, taking into account the rock density (Equation 3) and the hourly productivity of the mine (Equation 2), 
we made sure that the AM-75 roadheader with a passport minute productivity $Q_{\text {roadh.m }}=$ $0.5 \mathrm{~m}^{3} / \mathrm{min}$, fully meets the requirements for ensuring annual production mineral resource.

As a result, we conclude that the proposed methodology for productivity calculation and selection a mining roadheader, which takes into account mining opportunities and the economic feasibility of the mine life, proved itself viable.

\subsection{Calculation and Construction of Load Diagrams using the Equivalent Force Method}

The studied roadheader has already been in operation for several years at other mines and has been exposed to an aggressive mining environment (gases, mine dust, and brines containing sulfate ions), as well as to mechanical stress during rock caving. Therefore, the diagnostics of its electrical equipment has already been carried out, and significant problems were identified in the operation of the electric motors of the roadheader mechanisms (Egorov et al., 2019a). To replace the failed electric motors, it was proposed to use Russian counterparts, and so we present their calculations and preliminary selection (Liu et al., 2018; Eshchin, 2019). The preliminary selection of electric motors requires the construction of load diagrams for the mechanisms (Kopylov et al., 2019; Okolnishnikov et al., 2019).

We first calculate the parameters of the load diagram for the most powerful mechanism, the roadheader cutter. The rotary force of the roadheader cutter while idle and the cutter's cutting force on the rock is as follows:

$$
F_{\text {idle }}=m_{W} \cdot g \cdot \mu_{1}, F_{w}=m_{W} \cdot g \cdot \mu_{2} \cdot \rho,[N]
$$

where $\mu_{1}(=0.1 \div 0.15)$ is the coefficient of friction of the cutter (metal-metal), $\mu_{2}(=0.4 \div 0.6)$ is the coefficient of friction of the cutter on the rock (metal-stone), $\mathrm{m}_{\mathrm{W}}$ is the working body weight (Table 1$)$, and $g\left(=9.8 \mathrm{~m} / \mathrm{s}^{2}\right)$ is the gravity acceleration.

The idle working, the on-load working, and cycle times are equal to:

$$
t_{\text {idle }}=\frac{L_{S}}{V_{R m}}, t_{W}=\frac{S_{P} \cdot Q_{\text {roadh.m }} \cdot \rho \cdot 1000}{V_{W} \cdot m_{W}}, t_{c}=2 \cdot t_{\text {idle }}+t_{w},[\mathrm{~min}],
$$

where $L s$ is the distance from the parking area to the face in metres; $V_{\mathrm{Rm}}(=8.8 \mathrm{~m} / \mathrm{min})$ is the average travel speed of the roadheader assessed during its exploitation; $S_{\mathrm{P}}\left(=24 \mathrm{~m}^{2}\right)$ is the roadway area; $V_{\mathrm{w}}(=1.4 \mathrm{~m} / \mathrm{s}=84 \mathrm{~m} / \mathrm{min})$ is the rotational speed of the roadheader's cutter; and $Q_{\text {roadh.m }}$ is the minute productivity.

The equivalent force of the cutter during operation and preliminary motor power is calculated by the following formulas:

$$
F_{e q}=\sqrt{\frac{2 \cdot\left(F_{i d l e}^{2} \cdot t_{i d l e}\right)+F_{w}^{2} \cdot t_{w}}{t_{c}}},[N], N=\frac{F_{e q} \cdot Q_{\text {roadh } m}}{V_{W} \cdot 100 \cdot \eta_{a v}},[W]
$$

where $\eta_{a v}$ is the efficiency of the mechanism determined as the ratio of useful work to that performed during the previous operating experience of the roadheader.

The obtained motor power should be increased by $10 \%-15 \%$ to ensure reliability in case of potential overloads (Fedotov et al., 2016; Gracheva, 2019). This power is called installed power $\left(N_{\text {inst }}\right)$.

Table 2 shows the calculated parameters of all the main mechanisms of the roadheader: the working body, the loader, and the conveyor. The most powerful mechanism, the roadheader's cutter, has the greatest ratio of operating and idling force. The cycle time of the roadheader is the same for all its mechanisms. Installed power shows the minimum power of the mechanisms' electric motors required to create the necessary force during operation. The load diagrams for the roadheader's main mechanisms are shown in Figure $1 \mathrm{a}$. 
Table 2 Calculated parameters of the roadheader mechanisms

\begin{tabular}{lccc}
\hline \multirow{2}{*}{\multicolumn{1}{c}{ Parameter }} & \multicolumn{3}{c}{ Roadheader Mechanisms } \\
\cline { 2 - 4 } & Cutter & Loader & Conveyor \\
\hline Effort at idle speed, $F_{\text {idle }}(\mathrm{N})$ & 7350 & 2312 & 3372 \\
Working effort, $F_{w}(\mathrm{~N})$ & 59780 & 5685 & 12704 \\
Equivalent effort, $F_{\text {eq }}(\mathrm{N})$ & 54400 & 5209 & 11625 \\
Idle time, $t_{\text {idle }}(\mathrm{min})$ & 4.6 & 4.6 & 4.6 \\
Working time, $t_{w}(\mathrm{~min})$ & 43.4 & 43.4 & 43.4 \\
Cycle time, $t_{c}(\mathrm{~min})$ & 52.6 & 52.6 & 52.6 \\
Preliminary power, $N(\mathrm{~W})$ & 147800 & 29597 & 60549 \\
Installed power, $N_{\text {inst }}(\mathrm{kW})$ & 170 & 34 & 70 \\
\hline
\end{tabular}

Based on the calculations performed, asynchronous motors with a short-circuit rotor, which have the closest power values and are suitable in terms of voltage and operating mode, were selected from the catalogue. The technical parameters of the electric motors are given in Table 3.

Table 3 Selection of electric motors of the roadheader mechanisms

\begin{tabular}{lccc}
\hline \multirow{2}{*}{ Parameter } & \multicolumn{3}{c}{ Roadheader Mechanisms } \\
\cline { 2 - 4 } & Cutter & Loader & Conveyor \\
\hline Power, $P_{N}(\mathrm{~kW})$ & 200 & 37 & 75 \\
Rated rotation speed, $\omega_{N}(\mathrm{rad} / \mathrm{s})$ & 154.9 & 153.86 & 154.7 \\
Rated backslash, $s_{N},(\%)$ & 1.3 & 2 & 1.5 \\
Efficiency, $\eta$ & 0.94 & 0.925 & 0.94 \\
Starting moment to rated moment ratio, $k_{S}$ & 1.3 & 1.7 & 1.7 \\
Maximum moment to rated moment ratio, $k_{M}$ & 2.2 & 2.7 & 2.5 \\
Moment of inertia, $J\left(\mathrm{~kg} \cdot \mathrm{m}^{2}\right)$ & 3.63 & 0.28 & 0.89 \\
\hline
\end{tabular}

Table 3 shows that the power of the selected electric motors almost completely coincides with the passport data for the motors of roadheader mechanisms from Table 1. This indicates the successful testing of the method of equivalent forces for calculation and selection electric motors for rotary (continuous) action mechanisms.

\subsection{Calculation and Construction of Static Characteristics using Reduced Moments}

The construction of a load diagram and tachogram of electric motors requires the calculation of the gear-reduction ratio, reduction of static resistance moments, and operating speeds of the motor shaft and taking the dynamic moment and acceleration of electric motor, taking into account the motor's overload capacity (Egorov, et al., 2019b). Rated, starting, and maximum motor moments are determined by the following formulas:

$$
M_{N}=P_{N} / \omega_{N}, M_{S}=k_{S} \cdot M_{N}, M_{M}=k_{M} \cdot M_{N},[N \cdot m]
$$

where $P_{N}$ is the rated moment, $k_{s}$ and $k_{M}$ are the ratio of starting and maximum moment to rated moment, $\omega_{N}$ is the rated rotation speed of motor, in radians per second.

Static resistance moments reduced to the motor shaft at operating force, at idling speed, and the dynamic moment of the motor according to the condition of maximum utilization of motor by overload capacity are calculated as follows:

$$
M_{S w, \text { Sidle }}=\frac{F_{w, i d l e} \cdot V_{R} \cdot \pi}{\omega_{N} \cdot \eta}+M_{N},[N \cdot m], M_{d y n}=k_{P} \cdot\left(M_{M}-M_{S w}\right),[N \cdot m],
$$

where $\eta$ is motor efficiency; $F_{w, i d l e}$ are working and idle forces, respectively, which are determined by Equation 4 of the previous section; $V_{R}$ is the speed (rotation) of the 
mechanism in metres per second; and $k_{P}$ is a ratio that takes into account the overshoot of the moment on the corrected load diagram.

In order to draw the load diagram, it is divided into three intervals. To determine the acceleration of the motor shaft, acceleration and deceleration time and the values of moments in these intervals, the following formulas are used:

$$
\varepsilon=M_{d y n} / J,\left[\frac{\mathrm{rad}}{\mathrm{s}^{2}}\right], t_{1,3}=\omega_{N} / \varepsilon,[s], M_{1,3}=M_{\text {dyn }} \pm M_{\text {Sidle }},[N \cdot \mathrm{m}]
$$

The duration of operation of electric motors with a constant speed depends on the mechanism type, its operation mode, and technological conditions. In the considered case, for a mining roadheader, the technological process consists of stoping of the mining area, so the operating time and motor moment will be determined as:

$$
t_{2}=\frac{S_{P} \cdot Q_{\text {roadh } m} \cdot \rho \cdot 10^{3}}{V_{R} \cdot m_{M} \cdot 60},[\mathrm{~min}], M_{2}=M_{S W}[N \cdot \mathrm{m}]
$$

where $S_{P}$ is the roadway area in square metres.

The results of calculating and constructing a load diagram and tachogram for the most powerful electric motor of a mining roadheader, performed using the MathCAD package (Egorov et al., 2020), are shown in Figure 1b.

Further, we calculate and build the motor mechanical characteristic defined as the dependence of the angular speed of rotation $\omega$ on the electromagnetic moment of the motor $M$ - i.e., obtain the function $f=\omega(M)$. For this purpose, the authors use the Kloss formula, setting the slip values from 0 to 1 and inserting it in the expression:

$$
M=2 \cdot M_{M a x} \cdot \frac{1+a \cdot s_{c r}}{\frac{s}{s_{C r}}+\frac{s_{C r}}{s}+2 \cdot a \cdot s_{c r}},[N \cdot m]
$$

where $a\left(=R_{S} / R_{r}\right)$ is the winding ratio; $R_{S}$ is the stator winding resistance in ohms; and $R_{S}$ is the rotor winding resistance in ohms. The results of the calculation and construction of the mechanical characteristics of the cutter electric motor, performed using the MathCAD package, are shown in Figure 1c.

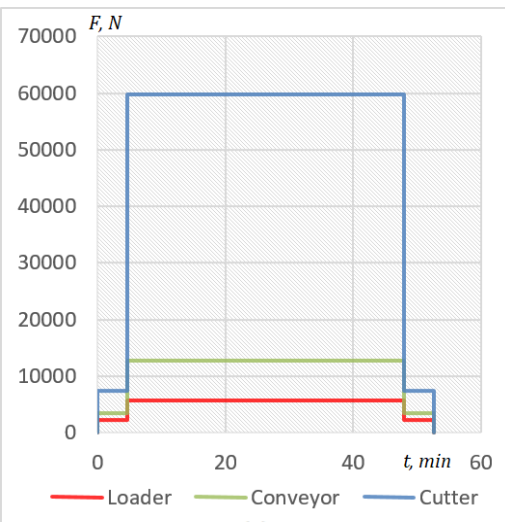

(a)

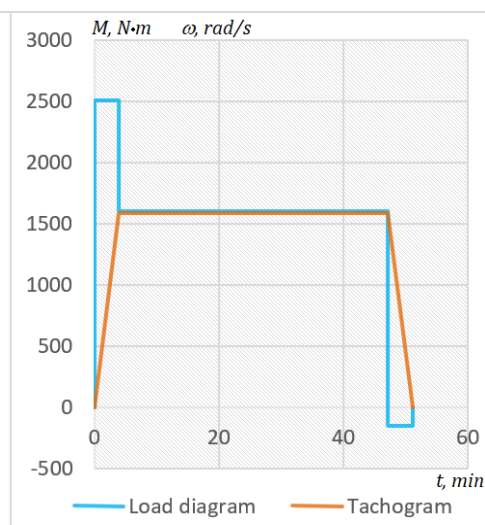

(b)

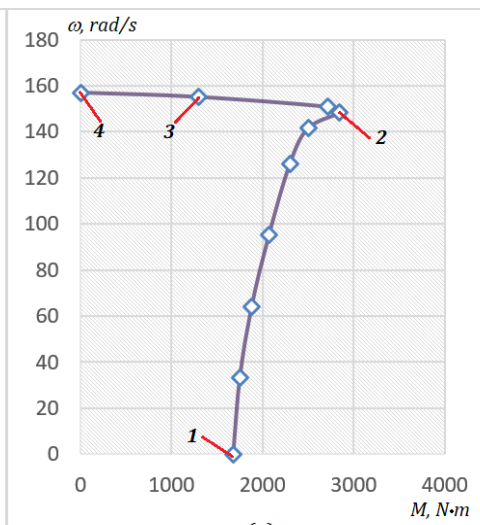

(c)

Figure 1 Load diagrams of the roadheader mechanisms (a), load diagram and tachogram (b), and mechanical characteristics (c) of the electric motor of the roadheader's cutter

There are four points in Figure 1c, typical for an asynchronous motor: (1) the motor start moment; (2) the critical operation mode; (3) typical operation; and (4) the ideal noload point. Since the operating moment-point does not exceed the value of the starting and critical moments, it can be assumed that the electric motors were selected correctly. 
It is also worth noting that this method for determining the reduced moments was not previously used to calculate the static and dynamic characteristics of the mechanisms of technological units of the mine, but was used mainly for mechanisms with a low-variable load (for example, fans, compressors, and pumps), and was modified by the authors specifically for the mining roadheader.

When all the calculations have been made and the necessary characteristics have been built, we proceed to the computer modeling of the electric drive system of the mining roadheader, which will help assess the correctness of the calculations.

\subsection{Development of a Computer Model and Analysis of Results}

To develop and implement a computer model of the AM-75 multimotor electric drive system in the MatLab software package, we use the Simulink application (Muhammad et al., 2015) - namely, the SimPowerSystems block library subdirectory. The models of electromechanical systems created in MatLab are described in detail in Egorov et al. (2020) and Sinha et al. (2018). The computer model is shown in Figure 2a. Figure $2 \mathrm{~b}$ presents the simulation results obtained by the oscilloscope. The angular speed of rotation and the electromagnetic moment of the electric motors of the roadheader's electric drive system are considered.

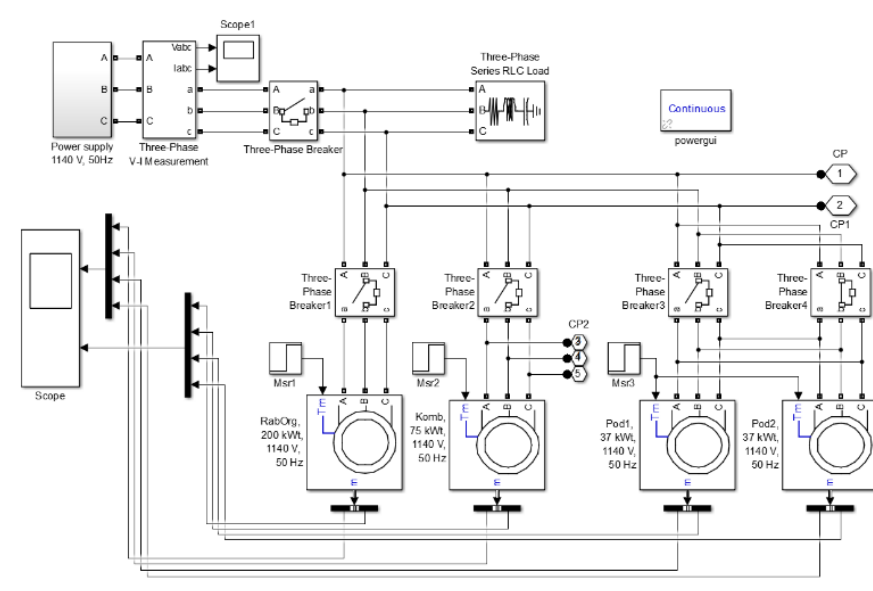

(a)

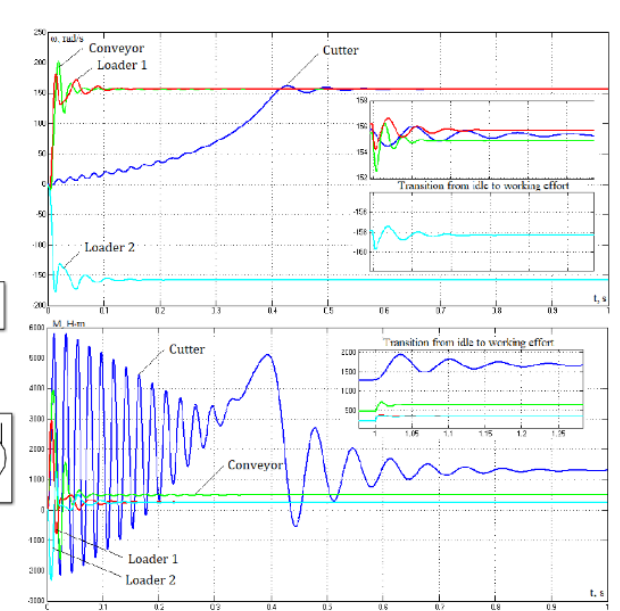

(b)

Figure 2 Computer model of the multimotor electric drive system of a mining roadheader (a) and results of computer modeling (b)

The upper graph in Figure $2 \mathrm{~b}$ shows the angular speed of the motor's rotation. The working body's most powerful electric motor starts up in $0.5 \mathrm{~s}$, while the less powerful motors reach their rated speed in $0.1 \mathrm{~s}$. The lower graph shows the motors' electromagnetic moment. The ratio of the starting moment to the rated moment exceeds the permissible values by several times. This process negatively affects the starting current and, as a result, the power consumption. As a result of the appearance of an additional moment of static resistance, the motors develop an additional electromagnetic moment, and the angular speed of rotation is slightly reduced. The results of comparing the simulation results with the calculated data obtained earlier (angular rotation speed of the motors and their electromagnetic moment) and the determined errors are presented in Table 4.

Table 4 shows that there are slight deviations between the calculated and modeled angular rotation speeds and the electromagnetic moments of the motors of the mining machine mechanisms, which do not exceed $2 \%$. The results of successful computer modeling confirmed the correctness of the calculations performed. It can be concluded that the methods developed by the authors and applied in this study are workable and can be 
used for the calculation and selection of mining roadheaders in the diamond-mining industry.

Table 4 Comparison of simulation results with the calculated data

\begin{tabular}{lccc}
\hline \multicolumn{1}{c}{ Characteristics } & $\begin{array}{c}\text { Calculated } \\
\text { value }\end{array}$ & $\begin{array}{c}\text { Results of } \\
\text { modeling }\end{array}$ & $\begin{array}{c}\text { Error, } \\
\%\end{array}$ \\
\hline Angular rotation speed of the cutter motor, rad/s & 154.9 & 154.2 & 0.45 \\
Angular rotation speed of the conveyor motor, rad/s & 154.7 & 156.3 & 1.02 \\
Angular rotation speed of the loader motor, rad/s & 153.86 & 155.8 & 1.24 \\
Moment of the cutter motor, $\mathrm{N} \cdot \mathrm{m}$ & 1291.1 & 1292 & 0.07 \\
Moment of the conveyor motor, $\mathrm{N} \cdot \mathrm{m}$ & 484.8 & 480.2 & 0.95 \\
Moment of the loader motor, $\mathrm{N} \cdot \mathrm{m}$ & 240.5 & 243.5 & 1.23 \\
\hline
\end{tabular}

\section{Conclusions}

The calculations resulted in the construction of load diagrams and static characteristics of a multimotor electric drive system of a mining roadheader using the methods of equivalent forces and reduced moments. Computer modeling was carried out, confirming the correctness of the calculations. Such studies are relevant for the global diamond-mining industry (Sedelnikova et al., 2019; Volotkovskaya et al., 2020). Based on the calculated equivalent forces, the preliminary and installation capacities of electric motors, which were subject to replacement due to failure, were obtained. Subsequently, three-phase asynchronous motors with a short-circuit rotor were selected from the available models. The equivalent force method is suitable for rotational mechanisms, showing a low absolute error between calculated and passport data, which is confirmed by computer modeling. The static characteristics of the selected electric motors were built on the basis of calculated reduced moments. These characteristics confirm the correctness of the motor selection. The calculations and computer modeling are useful for further computer simulation of the operation of electric drive systems of a mining roadheader and the power supply system of a mining site (Semenov et al., 2019a; Semenov et al., 2019b). In dangerous conditions such as underground mines, computer modeling is the only possible tool for further evaluation of power quality in the underground parts of the mine not accessible for experimental research and physical measurements (Semenov and Kuznetsov, 2014; Fedorov, 2017; Shpiganovich et al., 2017; Shevyrev et al., 2018).

\section{Acknowledgements}

The paper was funded by the Russian Scientific Foundation, project 21-79-20124 "Modeling of Electric Power Complexes and Systems Based on Theoretical and Experimental Research".

\section{References}

Cehlar, M., Zhironkin, S.A., Zhironkina, O.V., 2019. Horizons of Convergent Development of Open Pit Geotechnol-Ogy in the 21St Century: World Experience. Vestnik of Kuzbass State Technical University, Volume 133(3), pp. 94-102

Chaadaev, A.S., Zyryanov, I.V., Kirillov, D.S., Bondarenko, I.F., 2015. Creation and Industrial Introduction of Underground Mining Systems for Diamond Deposits of ALROSA. Gornyi Zhurnal, Volume 2015(11), pp. 48-52

Chanturia, V.A., Bondar, S.S., Godun, K.V., Goryachev, B.E., 2015. Diamond Industry in Russia and in the World's Top Diamond Producing Countries: State-of-the-art. Gornyi Zhurnal, 
Volume 2015(3), pp. 67-75

Egorov, A.N., Semenov, A.S., Bebikhov, Y.V., Sigaenko, A.A. 2019. Assessment of the Energy Efficient of the Modernized Main Fan Unit of the Underground Mine. International Journal of Energy for a Clean Environment, Volume 20(2), pp. 153-165

Egorov, A.N., Semenov, A.S., Kharitonov, Y.S., Fedorov, O.V., 2019. Efficiency of Variable Frequency Drive in Diamond Mining. Gornyi Zhurnal, Volume (2), pp. 77-82

Egorov, A.N., Kharitonov, Y.S., Shevchuk, V.A., Semenov, A.S., 2020. Influence of High Harmonics on a Frequency Converter Operation in Underground Mining. Bulletin of the Tomsk Polytechnic University, Geo Assets Engineering, Volume 331(6), pp. 141-151

Eshchin, E.K., 2019. Scraper Face Conveyors Dynamic Load Control. Journal of Mining Institute, Volume 239, pp. 570-575

Fedorov, O.V., 2017. Expeditious Forecasting of Power Consumption. In: 2017 International Conference on Industrial Engineering, Applications and Manufacturing, ICIEAM 2017 Proceedings (p. 8076221). New York, USA: Curran Associates

Fedotov, A.I., Gracheva, E.I., Fedotov, E.A., Chernova, N.V., 2016. Local Fourier Transformation Application for Mathematic Modeling of Synchronous Machine Valve Actuator. Journal of Engineering and Applied Sciences, Volume 11(13), pp. 2939-2945

Ges.M.B.H, V.-A.B., 2009. Operating instructions AM 75/162

Gracheva, E.I., Naumov, O.V., Gorlov, A.N., 2019. Influence of Value Resistance Contact Units of Switching Devices on Losses of the Electric Power in Shop Networks of Low Tension. IOP Conference Series: Materials Science and Engineering, Volume 643(1), pp. 1-6

Hrinov, V., Khorolskyi, A., 2018. Improving the Process of Coal Extraction based on the Parameter Optimization of Mining Equipment. E3S Web of Conferences, Volume 60, 00017

Kopylov, K.N., Kubrin, S.S., Zakorshmenniy, I.M., Reshetniak, S.N., 2019. Reserves of Increase of Efficiency of Coal Extraction Sections of Coal Mines. Ugol, Volume 3, pp. 46-49

Liu, Y., Hou, L., Qin, D., Zhang, Y., 2018. Self-adaptive Control of Roadheader based on Cutting Resistance Recognition. International Journal of Advanced Manufacturing Technology, Volume 94(9-12), pp. 3553-3561

Odnokopylov, G.I., Bukreev, V.G., Shevchuk, V.A., Shilin, A.A., 2019. Exploration AC Electrical Machines Operational Reliability in Mining Industry. In: Proceedings of Tomsk State University of Control Systems and Radioelectronics, Volume 22(3), pp. 125-131

Okolnishnikov, V.V., Ordin, A.A., Rudometov, S.V., 2019. Modeling of Underground Coal Mining Processes. Optoelectronics, Instrumentation and Data Processing, Volume 55(4), pp. 383-387

Muhammad, A.H., Hasbullah, M., Djabbar, M.A., Handayani, 2015. Comparison between Conventional and Azimuthing Podded Propulsion on Maneuvering of a Ferry Utilizing MATLAB Simulink Program. International Journal of Technology, Volume 6(3), pp. 452461

Sedelnikova, I.M., Fedorov, O.V., Yakusheva, A.M., 2019. Improving Enterprise Production Management System on the Basis of Lean Production. International Journal of Economics, Finance and Management Sciences, Volume 7(6), pp. 210-214

Semenov, A.S., Kuznetsov, N.M., 2014. An Analysis of the Results of Monitoring the Quality of Electric Power in an Underground Mine. Measurement Techniques, Volume 57(4), pp. 417-420

Semenov, A.S., Egorov, A.N., Khubieva, V.M., 2019a. Assessment of Energy Efficiency of Electric Drives of Technological Units at Mining Enterprises by Mathematical Modeling Method. In: 2019 International Conference on Industrial Engineering, Applications and Manufacturing, ICIEAM 2019 (p. 8743025). New York, USA: Curran Associates 
Semenov, A.S., Semenova, M.N., Bebikhov, Y.V., 2019b. Development of Universal Mathematical Model of Electrical Power Supply System of Area of Industrial Enterprise. In: Proceedings - 2019 International Russian Automation Conference, RusAutoCon 2019

Shevyrev, Y.V., Fedorov, O.V., Sarvarov, A.S., 2018. Technology State-of-the-Art and Supply of Resources. Mining Informational and Analytical Bulletin, Volume 3, pp. 82-90

Shpiganovich, A.A., Fedorov, O.V., Pushnitsa, K., Churkina, E.V., 2017. Simulation of Switching Overvoltages in Power Supply Systems of Metallurgical Plants. Izvestiya Ferrous Metallurgy, Volume 60(9), pp. 726-731

Sinha, A.K., Das, S., Chatterjee, T.K., 2018 Wavelet Transform Based Ball Bearing Fault Detection Scheme for Heavy Duty Mining Electrical Motors under Supply Frequency Regulation using MCSA. International Journal of Technology, Volume 9(1), pp. 170-180

Sutresman, O., Syam, R., Asmal, S., 2017. Controlling Unmanned Surface Vehicle Rocket using GPS Tracking Method. International Journal of Technology, Volume 8(4), pp. 709718

Volotkovskaya, N.S., Semenov, A.S., Fedorov, O.V., 2020. Feasibility of Energy Sector Development and Optimization Program of the Republic of Sakha (Yakutia). IOP Conference Series: Materials Science and Engineering, Volume 753(8), pp. 1-5 